\title{
Treatment related myeloid malignancies in childhood
}

\author{
Henk van den Berg \\ Correspondence: h.vandenberg@amc.uva.nl

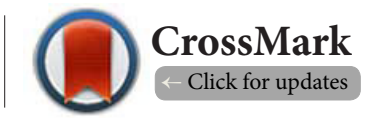

Department of Pediatric Oncology, Emma Children Hospital Academic Medical Centre, University of Amsterdam, The Netherlands.

\begin{abstract}
Incidence of treatment related AML/MDS (t-AML/MDS) in children is extremely low. Consequently assessment of data from adults and to some extent extrapolation from adults is needed. Epipodophyllotoxin induced t-AML/MDS is more common, which is likely to be related to the shorter latency period, FAB-M4, FAB-M5, APL, balanced karyotypes, 11q23 and 21q22 anomalies, inv(16) and $t(15 ; 17)$ are noted more often. Duration and short interval between administrations of epipodophyllotoxins results in higher incidence of t-AML/MDS. Genetic (karyotypic) make up influence duration of remission, although the relation with overall-survival is less clear. Choice of therapy should be based on co-morbidity and the likelihood to undergo intensive therapy. The majority of children with $\mathrm{t}-\mathrm{AML} / \mathrm{MDS}$ should have a transplantation. A minority of children with $\mathrm{t}-\mathrm{AML}$ with inv(16), $\mathrm{t}(8 ; 21)$ and $t(15 ; 19)$ should be considered for chemotherapy according to de-novo protocols. Monitoring of early response criteria for detection of primary resistance is advised.
\end{abstract}

Keywords: Leukemia, aml, children, secondary, alkylating agents, epipodophyllotoxins, etoposide

\section{Introduction}

Myeloid malignancies represent a number of clonal hematopoietic disorders with extensive production of non-differentiating myeloid precursors cells. Due to infiltration in the bone marrow limiting production of normal cells, anemia, thrombocytopenia and neutropenia are often the first signs of the disease. Myeloid malignancies are mostly denominated as leukemias and myelodysplasia (MDS) and are delineated by the percentage and characteristics of the malignant cells and are classified in the same WHO category. Most patients with myeloid malignancies have no preceding disease. For those patients with a preceding disease, which is related to the development of a myeloid malignancy, a separate entity exists and is defined as "Acute myeloid leukemia and myelodysplastic syndromes, therapy related". A subclassification was based on major related inducing factors; i.e., 1. Alkylating agent/radiation-related type, 2. Topoisomerase II inhibitor-related type; 3. Others [1]. This remaining subclassification; i.e., "others", includes cases related to e.g., fludarabine, chlorambucil and radiotherapy/radioactive isotopes [2-6]. An additional cause of t-AML is immune suppression; e.g., due to azathioprine [7]. Since most patients had combinations of inducing agents this WHO subclassification is currently not seen as relevant [8]. Generally both therapyrelated $\mathrm{AML}$ of secondary-AML terms are used.

\section{Review \\ Incidence}

Incidence of acute myeloid leukemia in children is low. Based on SEER data an incidence rate of 0.7 cases of AML per 100,000 children in the age group $<20$ years is noted. No epidemiological data exist on the incidence of t-AML/MDS. St. Jude's Hospital reports on $36(1 \%)$ out of 3,696 children over a 12 year period [9]. Literature data indicate that around 6 to $13 \%$ of AML cases, irrespective of age, can be designated as t-AML/MDS $[10,11]$. In a study on 642 children who had suffered from ALL and who developed a secondary malignancy t-AML/MDS was seen in 255 children; i.e., AML in 186, MDS in 69 children [12]. After a prolonged follow-up after being cured of their primary malignancy, an increment in incidence in secondary malignancies is noted, with a total ratio of observed versus expected cases of 6603 for MDS and 226 for AML [13]. In a followup study on 14359 5-year survivors of childhood cancer 1402 patients developed 2703 neoplasms, among them $24 \mathrm{t}-\mathrm{AML}$ and 11 undefined non-ALL leukemia, resulting in a standardized increased risk (SIR) of 9.3 for all treatment related malignancies and specific for t-AML/MDS a SIR of 6.0 [14]. In a long follow-up study on 1378 patients surviving pediatric cancer, the standardized mortality rates (SMR) from secondary cancers tend to decrease from 38.1 to 6.19 , after follow-up from the first decade to $>25$ years follow-up after initial diagnosis, respectively. A similar reduction was seen calculating the absolute excess risk (AER; decrease from 1.75 to 1.05 per 1,000 patient years). Only $16 \%$ were t-AML/MDS. Explanatory for the lowering of AER and SMR is the increase due to other cancers at older age in the normal population. A factor influencing the observed decrease in incidence rate in more recently treated children is 
Henk Van Den Berg, Hematology and Leukemia 2014,

http://www.hoajonline.com/journals/pdf/2052-434X-2-3.pdf

doi: $10.7243 / 2052-434 X-2-3$

the striving to reduce the alkylator dose as well as the trend to irradiate less often, reducing irradiation dosages and limiting irradiation fields [15-17].

\section{Diagnosis}

Clinical symptoms and physical findings of t-AML/MDS are to some extent similar to de-novo AML/MDS. Signs of leukemia are more often linked to hyperleukocytosis and cytopenias of normal cells, whereas MDS results in most cases in cytopenias; leading to tiredness, infections and bruises. The primary diagnosis is based on morphology and histochemical staining. Subtyping is done similar to de-novo AML/MDS and based on the FAB-classification. Epiphyllotoxins and anthracyclines/ mitoxantrone related secondary myeloid malignancies are mainly FAB-M4 (among them M4eo inv (16)), M5 and acute promyelocytic leukemia (APL-FAB- M3 t $(15 ; 17))$ presenting as acute onset disease. Alkylating agent related t-AML/MDS more often present as FAB-M6 and -M7 subtypes. Secondary myeloid malignancies related to alkylating agents have (in contrast to epipodophyllotoxins related mali-gnancies) a more protracted course presenting initially in many cases as MDS [15]. It was shown that the dominant clone in t-AML as seen after preceding t-MDS is derived by further evolution from the MDS clone [18]. In adults there is a relation on incidence with type of alkylating agent and occurrence of t-AML/MDS. It is claimed that melphalan induced more often secondary AML as compared to cyclophosphamide. Dose relationships were noted for cyclophosphamide [19-21].

Similar to de-novo AML in M4 and M5 subtypes a high frequency of rearrangements of $11 \mathrm{q} 23$ anomalies, $\mathrm{t}(8 ; 21)$, inv(16) and $t(8 ; 16)$ are noted [22]. Compared to de-novo AML, the incidence of polyclonality is higher in t-AML/MDS. Secondary APL forms a peculiar exception; it has been found to be similar to de-novo APL in respect to morphology, immunology and cytogenetics [23].

\section{Adults}

In adults often an initial phase compatible with MDS evolving in to AML is common. In children this is not as usual. In adults the percentage of patients presenting with a t-MDS (in contrast to t-AML) is substantially higher as compared to adults [24]. Higher rates of uncommon AML subtypes such as FAB-M6 and $M 7$, i.e., erythroblastic and megakaryoblastic $A M L$, are noted in t-AML in contrast to de-novo AML. In adults a peak incidence is noted 4-6 years after cytotoxic therapy given for the first malignancy. Occurrence after a latency period as short as 12 months but even ranging to 15-20 years are not uncommon.

\section{Children}

It is stated that in children the occurrence of $\mathrm{t}-\mathrm{AML}$ is negligible 6-years after treatment cessation of the primary disease [25]. Also the latency period to development of t-AML/ MDS was found to be the same for alkylator-induced as for topoisomerase induced myeloid leukaemia [26]. This might in part be related to the age limits restricting the standard follow-up period by paediatricians and is in contrast to findings in adults. The number of patients included in the cited document was also low $(n=24)$ and low-risk t-AML/ MDS related to epipodophyllotoxin cases are absent in the report. In adults epipodophyllotoxins related AML tends to present between 1-4.5 years, and a preceding MDS phase is often lacking, whereas alkyting agents induced-AML often occurs after 1-20 years $[10,21,27]$. As a result reports on only children may have missed a part of alkylator induced t-AML/ MDS and/or the epipodophyllotoxin related low-risk patients.

\section{Cytogenetics}

Distribution of karyotype aberrations is different from de-novo AML since more $11 \mathrm{q} 23$ and complex karyotypes are noted [10]. T-AML patients more often have a balanced karyotype as compared to patients with t-MDS [27]. Also in relation to the preceding therapy differences are noted. Alkylating agents are linked more frequently with cytogenetic anomalies involving chromosomes 5 and 7 . The latter anomalies were noted in $76 \%$ cases in a series of 306 patients, which is substantially higher as compared to de-novo AML $[\mathbf{2 8 , 2 9 ]}$. Affymetrix mapping confirmed the occurrence of single nucleoside polymorphism (SNP) in a subset of patients with loss of chromosomes 5 and/ or 7, which was associated in that study with prior treatment with alkylating agents [30]. In topoisomerase II inhibitor related secondary AML more balanced translocations are noted; more often involving $11 \mathrm{q} 23$ and 21q22. Translocations related with epipodophyllotoxins involving $21 \mathrm{q} 22$, inv $(16)$ and $t(15 ; 17)$ have received more often anthracyclines as well [25,31-39]. These findings were also confirmed for children in a study on 20 patients [40]. However, 11q23 and 21q23 abnormalities have been identified in non-anthracycline treated patients as well [9]. Further DNA analysis revealed in epipodophyllotoxin related t-AML/MDS MLL-rearrangements, EML1-1, CBF $\beta$-MYH1 1 and PML-RARa. Whereas in alkylating agent specific genetic aberrations are less specific [15]. It is hypothesized that the differences between alkylator induced and epipodophyllotoxin induced t-AML/MDS in respect both to latency to develop a t-AML and chromosomal findings are related to differences in oncogene alterations. In alkylating agent induced t-AML/ MDS multiple tumor suppressor or oncogenes are needed to induce a malignancy, resulting in imbalanced karyotypes. Epipodophyllotoxins result in balanced karyotypes related to an activation of an oncogene in a dominant fashion [21]. Several pathways more or less specific for either alkylator- or epipodophyllotoxins have been constructed; it is beyond this review to discuss these hypotheses [41].

\section{Risk factors}

Secondary myeloid malignancies are in the majority of cases related to cytotoxic chemotherapy and organic compounds such as benzene [42]. Earliest reports date from Hodgkin pat- 
ients receiving mechlorethamine, vincristine, procarbazine and prednisone (MOPP) courses. In patients treated before the age of 16 years, the relative risk of leukemia was about 80 times higher than the control population (relative risk of 321.3). After replacing mechlorethamine by cyclophosphamide a lower SIR of 122 was found. After introducing doxorubicin, bleomycin, vinblastine and dacarbazine (ABVD) another reduction was noted [15,43-46]. Cytostatic drugs most commonly linked with secondary malignancies are topoisomerase II inhibitors (epipodophyllotoxins, anthracyclines and anthracenediones) and alkylating agents. Topoismerase inhibitors interfere with the enzymes involved in uncoiling the DNA in order to form single strands. This results in deletions, insertions, inversions and translocations [8]. Additional risk factors related to the use of medication are duration of exposure and cumulative dosage [47]. Cyclophosphamide has been mentioned earlier. In respect to cumulative and duration of administration of epipodophyllotoxins several reports mention the link of a higher cumulative dosage and a higher risk $[4 \mathbf{4 8 , 4 9 ]}$. Others do not confirm such a finding, but link the risk to the dosing schedule. They noted that higher cumulative dosages did not result in increased incidence rates, but prolonged administration had a more pronounced effect [50]. Being the most prominent factor of secondary malignancies noted in children; pediatric data are available on the increase related to the dosing interval. Prolonged administration of epipodophyllotoxin twice weekly or weekly was independently associated with the development of secondary AML. The overall cumulative risk of AML at six years was 3.8 percent; but in subgroups treated twice weekly or weekly, the risks were 12.3 percent and 12.4 percent [51]. Alkylating agents act by transferring alkylgroups to oxygen or nitrogen atoms of DNA bases. Alkylating agents with two active sites are additionally capable of cross linking DNA strands. Effects of alkylating agents on SIR are less clearly reported. In most cases they are used in combination with other chemotherapy. As a result the exact effect on induction of $t-A M L / M D S$ is less elucidated. It is claimed that anthracenediones (mitoxantrone e.g.,) induce more frequently secondary t-AML as compared to anthracyclines. However, data are mainly based on adults [52-55]. The effects of other agents may be clarified in the future. For instance campthotecans are potential candidates since the mode of action, i.e., blocking topoisomerase $\mathrm{l}$, is quite similar to topoisomerase II inhibitors. It is probable that due to the low number of patients treated with these compounds (in most cases in combination with other drugs) the leukemia inducing effect is still unnoticed [56].

High levels of irradiation and radioactive isotopes are reported to induce secondary myeloid malignancies $[6,9,57]$. lonizing irradiation induces the formation of reactive oxygen species through radiolysis of water molecules, which oxidize or deaminate DNA bases and induces DNA strand breakage. Proton irradiation leads to DNA strand breaks as well. It was described that radiotherapy as such is not related to t-AML/
MDS. However in combination with chemotherapy there was a clear relation $[33,58]$. The findings reported by others do not support the finding that radiotherapy given as single treatment modality is not related to induction of t-AML/MDS [27].

Synergy in respect to the induction of second malignancies in relation to other cytostatic drugs and host factors are well known as based on findings in Fanconi anemia, neurofibromatosis type 1 and gluthatione transferase polymorphisms [59-61]. An increase of risk of epipodophyllotoxin induced t-AML/MDS was related to the combination with other anticancer drugs. For asparaginase and alkylating agents, cisplatin and antimetabolites this has been reported as well. In respect to the effects of asparaginase a decrease of protein levels and as consequence a decrease in recombinogenesis activity is relevant in epipodophyllotoxin treatment. Which is explanatory for the increase of t-AML/MDS occurrence if asparaginase is given immediately before epipodophyllotoxin administration $[9,15,25,33,37,48,62,63]$.

Co-medication has been debated to play a role in induction of secondary malignancies. Especially the use of growth factors (G-CSF) and dexrazoxane have been under focus. In adults data on G-CSF are contradictory. An increased risk was found in breast cancer patients diagnosed at a younger age as compared with older patients $[\mathbf{5 2}, \mathbf{6 4}, \mathbf{6 5}]$. In children with Ewing sarcoma no relation was noted, whereas in ALL patients a relation was suggested $[66,67]$. In a study by Relling et al., on 412 children treated for ALL receiving etoposide and anthracyclines, 99 had received G-CSF, 284 cyclophosphamide, 58 of these 284 also received cranial irradiation. There were 20 children who developed t-AML/MDS after median interval of 2.3 years (range, $1.0-6.0$ years; $16 \mathrm{AML}, 3 \mathrm{MDS}$, and 1 chronic myeloid leukemia). The 6-year cumulative incidence of t-AML was $12.3 \%$ (5.3\%) Excluding children receiving irradiation, the incidence rate was higher in those receiving G-CSF ( $P=0.019)$ [67]. Although G-CSF is mentioned to be linked with the development of secondary malignancy, especially AML, this is at least in adults minimal with an absolute risk increase of $0.43 \%$. In contrast its use resulted in reduction of death (3.4\%) probably due to the possibly to give more intensive treatment schedule [68]. Dexrazoxane is used as agent giving cardioprotection to prevent side effects of anthracyclines. The induction of secondary malignancies is claimed by some. Others question such a side effect. As a result the product is only marketed for adults. The debate in children in respect to risk-benefit has not been finalized yet [69-71]. For both G-CSF and dexrazoxane the setting of this drug administered in relation to other carcinogenetic medication is probably of major importance in inducing t-AML/MDS.

Immune-suppression is related with secondary malignancies. Lymphomas are quite common, but AML is relatively scarce. In heart-lung recipients and kidney recipients relative risks of 5.5 and 2.1 for t-AML were reported. Non-DNA as well as DNA damaging immune-suppressants (e.g., azathioprine) are noted to be related with t-AML [7]. In hematopoietic stem 
Henk Van Den Berg, Hematology and Leukemia 2014,

cell transplantation patients a higher incidence as compared to patients treated without transplantation was reported in several manuscripts. However, administered cytostatic drugs and total body irradiation administered to these patients may be even more important in comparison with the resulting immune deficient state and the extensive cellular proliferation in these procedures [27,72-75]. In a study on 1487 paediatric autologous hematopoietic cell transplantation 35 secondary malignancies were noted; among them 6 cases with t-AML and 7 with t-MDS. For all secondary malignancies these children had a 24 times higher risk for developing a secondary malignancy, for AML and MDS the observed versus expected ratios were 266 and 6603 respectively. Analysis for specific risk factors did not reveal any significances [13].

Some inborn metabolic host factors are also linked with an increased susceptibility for t-AML/MDS. Low thiopurine-methyltransferase activity and polymorphism of a CYP3A4 enzyme results in as DNA-damaging metabolite of epipodophyllotoxins $[38,76,77]$. Also glutathione-S-transferase, $\mathrm{NAD}(\mathrm{P}) \mathrm{H}$ : quinine oxireductase and polymorphisms of DNA repair genes are linked with an increased occurrence of t-AML/MDS [28,36,78-87]. Extensive reviews on genetic susceptibility and biological pathogenesis were published $[\mathbf{2 1}, \mathbf{5 6 , 6 6 , 8 2}]$.

Some (often inheritable) anomalies attribute to the development of AML/MDS and AML/MDS without the need for prior therapy. In principle the term secondary AML/MDS is more applicable instead of treatment related AML/MDS. Based on similarities in disease characteristics some reports on t-AML/MDS deal with these anomalies, as well. Examples of genetic predisposition are Down syndrome, Fanconi anemia, Li-Fraumeni syndrome, Leopard syndrome, Noonan syndrome and Costello syndrome. Several of them are related to RAS-MAPK pathways [8,88-94]. The higher incidence of malignancies in relatives of patients with t-AML then in relatives of patients with de-novo AML and the occurrence of new malignancies in cancer patients treated with only surgery can be put forward for existence of yet unidentified factors [91]. As such it is assumed that at least some patients have an inheritable susceptibility to develop t-AML [7].

Patients with specific primary malignancies run an additional risk for t-AML/MDS; e.g., pediatric Hodgkin's lymphoma, osteosarcoma and APL after breast carcinoma $[49,95]$. The percentage of patients suffering from a specific secondary malignancy is not only related to former therapy; the primary disease itself is related to the distribution of type of malignancy as well. For instance t-AML is rare in chemotherapy treated patients with retinoblastoma treated who are prone to develop second malignancies. It is hypothesized that this is related to the fact that the underlying mutation of the $\mathrm{Rb} 1$ gene does not play a role in hematopoietic stem cells [96].

\section{Prognosis}

Since AML is more frequent in adults and t-AML/MDS only occurs after a preceding oncogenic exposure t-AML/MDS has a very low incidence in children. As a consequence many data have to be extrapolated from adults. In adults the prognosis of secondary $A M L$ is dismal in comparison with de-novo AML. However, remission rates reported range in a single report up to $82 \%$. But in an analysis of 13 different studies an overall CR rate was calculated to be $27 \%$. Survival at 5 years was reported to be less than $10 \%$. The recent study reported by Godley et al., states an overall survival at 1 year of $51 \%$. Overall survival at 1 year was $74 \%$ for patients who had achieved a CR, but only $20 \%$ for patients who had achieved only a partial remission after induction. After allogeneic stem cell transplantation median survival was 673 days, compared to 399 days for those who had an autologous transplant and 93 days in case no transplantation was done. Overall survival at 1 year was $72 \%$, $75 \%$, and $17 \%$ for patients respectively [27,97-101].

The number of children suffering from t-AML/MDS reported in literature is very low $[12,102-105]$. Tabori et al., reported on 21 children with t-AML and 2 with t-MDS. Both event free survival and overall survival were $14 \%$. Leahey et al., report on 11 children. Only 3 survived, resulting in a 3-years survival of $24 \%$. Causes of death were recurrence of primary disease and new malignancies [103]. Sandler reported on 16 children, 9 out of 13 children who achieved complete remission were transplanted. Two transplanted children survived over 2 years, whereas one not transplanted patient survived at least 8 months [104]. One of the larger studies reports on 62 children. Compared to de-novo AML they had a poorer induction rate ( $50 \%$ vs $72 \%$ ), overall survival ( $26 \%$ vs $47 \%$ at 3 years, and event-free survival (21\% vs $39 \%$ at 3 years) [15]. Children with $\mathrm{t}-\mathrm{AML} / \mathrm{MDS}$ who received intensive-timing induction had better outcomes than those who received standard-timing induction (overall survival $32 \%$ vs $0 \%$ ) [26]. In a study on 642 children who had suffered from ALL and later developed a secondary malignancy t-AML/MDS 5-year survival estimates for AML were $11.2 \%$ for 125 patients diagnosed before 2000 and $34.1 \%$ for 61 patients diagnosed after $2000(P<0.001)$; 5-year survival estimates for MDS were $17.1 \%$ for 36 patients and $48.2 \%$ for 33 patients, respectively. Allogeneic stem-cell transplantation failed to improve outcome of secondary myeloid malignancies after adjusting for waiting time to transplantation [12].

\section{Prognostic factors}

Adults

Dismal prognosis is related to age, and co-morbid conditions and restrictions in treatment due to preceding treatments [106-109]. In many cases t-AML/MDS is a fatal condition. Additionally factors are organ and vascular supply injury. Bone marrow function may be severely hampered due to cytostatic use and extensive irradiation $[108,110]$.

In respect to the preceding treatment alkylator related $t-A M L$ has a dismal prognosis, due to the more frequent harboring of anomalies of chromosomes 5 and 7. Remission rates of 24 and $26 \%$ were noted in t-AML versus 52 and $42 \%$ in de-novo 
AML. Long-term survival rates approximate $10 \%[108,111,112]$. On the other hand patients with t-AML due to epipodophyllotoxins are reported to have a better prognosis. In epipodophyllotoxins related cases remission rates are as high as $81 \%$, but ultimate outcome is still low; i.e., 8\% at 2-years [104]. In t-AML the expression rate of MDR1 is high. But in contrast to adults expression of the multidrug resistance gene MDR1 in children is expected to be (at least in de-novo AML) non-relevant [113]. Relevance in pediatric t-AML/MDS is undetermined.

\section{Genetics}

Prognosis in adults is related to the karyotype observed. Several classifications delineating prognostic groups exist (Table 1) [114-116]. A relative old report mentions that patients with $t(8 ; 21)(n=26)$, inv $(16)(n=16)$ and $t(15 ; 17)(n=6)$ have similar outcomes as compared to de-novo AML [117]. Schoch et al., defined, based on data of 93 patients that unfavorable anomalies were $3 q 21 q 26,5 q-/-5,7 q-/-7,11 q 23,12 p 17 p$, >2 abnormalities, intermediate anomalies (normal karyotype and other abnormalities) and favorable (i.e., $t(15 ; 17), t(8 ; 21)$ and inv (16)) karyotypes. Unfavorable karyotypes are more frequently noted in t-AML; i.e., favorable , intermediate and unfavorable karyotypes $26 \%$, $28 \%$ and $46 \%$ respectively. Rates in de-novo patients are 22 , 57 and $20 \%(p<0.001)$. Matching de-novo with therapy related cases only in patients with secondary AML with $\mathrm{t}(8 ; 21)$, inv (16) and $t(15 ; 17)$ a shorter overall survival was noted; higher relapse rate but similar $C R$ rate were noted. Among these karyotypes $t(8 ; 21)$ was found to have the poorest prognosis. Unfavorable and intermediate karyotypes had a similar outcome after matching for these anomalies of secondary versus de-novo patients. It was concluded that karyotypes were influencing survival duration, however ultimate prognosis irrespective of cytogenetic findings was very poor [10]. Similar findings for adults were reported from Chicago, 29 patients with t-AML with favorable cytogenetics had a median survival time of 27 months; those with intermediate cytogenetics had a survival time of 12 months which contrasted with 16 months for denovo AML. This was however not significant ( $p=0.19$ ). For $t-A M L$ and de-novo AML patients with unfavorable cytogenetics survival was 6 and 7 months, respectively $[29,118]$. In another report on adult patients from Germany a shorter survival time was noted in t-AML versus de-novo AML. In a later update of their study it was shown that karyotype is a factor in respect to duration of survival, but also in the favorable group 5-years overall survival is below $25 \%$ and a plateau is not reached $[10,119]$. Smith et al., reported similar data, however not all patients had received intensive remission induction chemotherapy. Even patients responding to therapy and patients with favorable karyotypes died either from t-AML or from their primary malignancy. The incidence of unfavorable karyotypes was over two-third, the worst prognosis was noted in patients with anomalies of chromosome 5 and 7 [27]. In a Korean report on outcome in 48 patients multivariate analysis showed that only APL and presence of non-complex karyotypes were related with a more profitable outcome [120]. For APL no differences as compared to de-novo AML were reported [121]. Which once again suggests, similar to the findings in morphological and immunological cell characteristics, that

Table 1. Risk groupings according to cytogenetics in literature.

\begin{tabular}{|c|c|c|c|c|c|c|}
\hline & \multirow[t]{2}{*}{ Stölzel et al., 2011} & \multirow[t]{2}{*}{ Kröger et al., 2009} & \multicolumn{2}{|c|}{ Litzow et al., 2011} & \multicolumn{2}{|c|}{ Armand et al., 2007} \\
\hline & & & AML & MDS & AML & $\begin{array}{l}\text { MDS or AML } \\
\text { arising from MDS }\end{array}$ \\
\hline $\begin{array}{l}\text { Low } \\
\text { (Stölzel/Kröger) } \\
\text { Favorable } \\
\text { (Armand) }\end{array}$ & $t(8 ; 21)$ or inv(16) & $\begin{array}{l}\text { normal and } t(8 ; 21) \text {, } \\
\text { inv } 16 \text { or } t(15 ; 17\end{array}$ & ns & ns & $\begin{array}{l}\mathrm{t}(8 ; 21) \text { alone } \\
\text { inv }(16 / \mathrm{t}(16 ; 16) / \operatorname{del}(16 \mathrm{q} 22) \\
\text { with } \mathrm{M} 4 \\
\mathrm{t}(15 ; 17)\end{array}$ & \\
\hline $\begin{array}{l}\text { Intermediate } \\
\text { (Stölzel/Kröger) } \\
\text { Standard } \\
\text { (Armand) }\end{array}$ & $\begin{array}{l}\text { patients not } \\
\text { harboring high- or } \\
\text { low-risk } \\
\text { aberrations }\end{array}$ & $\begin{array}{l}\text { one or two } \\
\text { abnormalities not } \\
\text { mentioned under } \\
\text { low or high risk }\end{array}$ & ns & ns & $\begin{array}{l}\text { Normal } \\
\operatorname{Del}(9 q) \\
\mathrm{t}(8 ; 21)+\operatorname{del}(9 \mathrm{q}) \text { or complex } \\
\text { Trisomy } 8 \\
\text { Abnormal } 5 \text { or } 7 \\
\text { Abnormal } 11 \mathrm{q} 23 \\
\text { All others }\end{array}$ & $\begin{array}{l}\text { Normal } \\
\text { Abnormal 3q } \\
\text { Abnormal } 5 \\
\text { Trisomy } 8 \\
\text { All others }\end{array}$ \\
\hline $\begin{array}{l}\text { High } \\
\text { (Stölzel/Kröger) } \\
\text { Adverse } \\
\text { (Armand) } \\
\text { Poor } \\
\text { (Litzow) }\end{array}$ & $\begin{array}{l}-5 / \operatorname{del}(5 \mathrm{q}) ;-7 / \text { del }(7 \mathrm{q}) ; \\
\text { monosomies of other } \\
\text { chromosomes (with } \\
\text { exception for the loss of } \\
\text { chromosomes X or } \\
\text { Y); inv }(3 \mathrm{q}) ; \text { abn } 12 \mathrm{p} ; \\
\text { abn } 11 \mathrm{q} ;+11 ;+13 ;+21 ; \\
+22 ; \mathrm{t}(6 ; 9) ; \mathrm{t}(9 ; 22) ; \\
\mathrm{t}(3 ; 3) \text {; complex } \\
\text { aberrant karyotype } \\
\text { ( } \geq \text { three independent } \\
\text { abnormalities) }\end{array}$ & $\begin{array}{l}11 \mathrm{q} ; \mathrm{t}(6 ; 9) ;-7 ; \\
\operatorname{del}(7 \mathrm{q}) ; \text { del } 5 \mathrm{q} \text { or } \\
\text { complex }(\geq 3)\end{array}$ & $\begin{array}{l}\operatorname{del}(5 \mathrm{q}) / 25, \\
27 / \operatorname{del}(7 \mathrm{q}), \text { abn } \\
3 \mathrm{q}, 9 \mathrm{q}, 11 \mathrm{q}, 20 \mathrm{q}, \\
21 \mathrm{q}, 17 \mathrm{p}, \mathrm{t}(6 ; 9), \\
\mathrm{t}(9 ; 22) \text { and } \\
\text { complex } \\
\text { karyotypes }(\geq 3 \\
\text { unrelated abn) }\end{array}$ & $\begin{array}{l}\text { complex (ie, } \geq 3 \\
\text { anomalies) or } \\
\text { chromosome } 7 \\
\text { abnormalities }\end{array}$ & $\begin{array}{l}\text { Complex } \\
t(9 ; 22) \\
t(6 ; 9)\end{array}$ & $\begin{array}{l}\text { Abnormal } 7 \\
\text { Complex }\end{array}$ \\
\hline
\end{tabular}

ns=not specified

${ }^{*}=$ restricted to post-hematopoietic transplantation patients 
Henk Van Den Berg, Hematology and Leukemia 2014,

http://www.hoajonline.com/journals/pdf/2052-434X-2-3.pdf

doi: 10.7243/2052-434X-2-3

t-APL is similar to the de-novo APL).

\section{FTL3}

In respect to FLT3 internal tandem duplications (FLT3-ITD) it was shown that the percentage expressing cells was significantly lower in t-AML, indicating that t-AML leukemogenesis in most cases follows mechanisms different from those seen in denovo AML. For de-novo AML FTL3-ITD was found to be a risk factor, for t-AML such conclusion was not made [122]. Also nucleophosmin-1 mutations were found to be less frequent in t-AML as compared to de-novo AML and presence was found to be a risk factor in patients below the age of 60 years [116].

\section{Transplantation}

In adults undergoing transplantation for t-AML/MDS 2-year survival rates of $30 \%$, relapse rates of $42 \%$ and treatment related mortality of $49 \%$ were reported in a French study [123]. In a series of 46 patients undergoing transplantation 5 -years disease-free survival was $24 \%$, relapse and non-relapse mortality was $31 \%$ and $44 \%$ respectively. In this cohort no statistical differences existed for patients treated with chemotherapy before conditioning for stem cell transplantation versus those who were not pretreated [124].

Patients after hematopoietic stem cell transplantation for their primary malignancy are at high risk since they have in the majority of cases a history with high dose irradiation and cytostatic use. In a report from the European Society for Blood and Marrow Transplantation t-AML and t-MDS multivariate analysis revealed a better prognosis in case of an age $<40$ years, normal cytogenetics and a status of $C R$ at the moment of transplantation; overall survival rates were $62 \%, 33 \%$ and $24 \%$ at 2 years, respectively. Cytogenetic anomalies were relevant, but sub-analysis on specific anomalies seemed not to be relevant in their prognostic scoring system (Table 2) [22].

In multivariable analyses on 2853 adults t-AML was an adverse prognostic factor for death in complete remission but not relapse as compared to de-novo AML. In contrast to older patients the younger patients were more intensively treated and did not show higher induction failures, but more relapse in complete remission. As a result it is suggested that co-morbidity, cumulative toxicity of cancer treatment,

Table 2. European society for blood and marrow transplantation risk scoring for $\mathrm{t}-\mathrm{AML} / \mathrm{MDS}$ (Kröger et al.,).

\begin{tabular}{lllll}
\hline Risk factor & \multicolumn{5}{c}{ Number of points } \\
\hline Age $>40$ years & \multicolumn{4}{c}{+2} \\
Not in complete remission & \multicolumn{4}{c}{+2} \\
Abnormal cytogenetics & \multicolumn{4}{c}{+1} \\
\hline Risk group & Overall & Relapse free & Non-relapse & Relapse \\
& survival & survival & mortality & rate \\
& (2 year) & (2 year) & (2 year) & (2 years) \\
\hline Low (0-1 factors) & $96 \%$ & $58 \%$ & $22 \%$ & $20 \%$ \\
Moderate (2-3 factors) & $33 \%$ & $32 \%$ & $37 \%$ & $31 \%$ \\
High-risk (4-5 factors) & $24 \%$ & $20 \%$ & $38 \%$ & $42 \%$ \\
\hline
\end{tabular}

inclusive the therapy for the first malignancy may therefore be important factors in the poor outcome of $\mathrm{t}$-AML patients in the early phase of treatment $[10,119,122,125]$. In a report from Seattle outcome was noted after correction for risk factors in HLA-identical or partially mismatched family hematopoietic transplantation. Relapse probability and relapse-free survival correlated significantly with disease stage and karyotypes. Relapse incidence was lower and relapse-free survival superior $(\mathrm{P}=0.02)$ with unrelated donor transplants. Their data also suggest that inferior outcome in patients with t-AML/MDS was related to the frequency of high-risk cytogenetics [126]. Similar findings were reported from the Dana Faber Cancer Institute [114]. A Danish report on 157 adults with t-AML and 473 de-novo AML patients showed in univariate analysis a better outcome for patients not reaching a complete remission. Differences were not significant after correction for age, cytogenetic anomalies, performance status and WBC [127].

\section{Children}

As already mentioned the data in children are scarce. A major difference is the more frequent relation with epipodophyllotoxins in children as compared with adults. Remission rates are as high as $81 \%$, but ultimate outcome is still low, i.e., $18 \%$ at 2-years [104]. In a study on 20 children only 3 children were alive after 1,12 and 68 months; no correlation was found with chromosomal abnormalities [40]. Hale et al., reported on epipodophyllotoxin induced t-AML in 19 children. Ten patients died from a relapse, and only 4 were alive 3 years after allogeneic transplant [102]. In a report on 38 allogeneic transplanted patients from St Judes Hospital 3-year overall and event free survival were both $15 \%$, the non-relapse mortality was found to be $60 \%$ at 3-years. Severe (grade III-IV) acute graft-versus-host disease and relapse rate were $24 \%$ and $19 \%$, respectively [128]. A report from the MD Anderson Hospital describes 22 patients from a group of 2589 children treated for a malignancy 2 -year survival rates of $20 \%, 40 \%$, and $25 \%$ in children who underwent stem cell transplantation without induction, children transplanted in remission after induction therapy and receiving a stem cell transplantation as salvage therapy, differences were not significant. Risk factors identified were poor/intermediate-risk cytogenetics $(p=0.01)$, lower hemoglobin level $(\mathrm{P}=0.0001)$, and $\mathrm{t}-\mathrm{MDS} / \mathrm{AML}$ (vs. de-novo) $(p=0.003$ ) [129]. Barnard et al., describe 24 children with t-AML/ MDS who were assigned randomly to standard- or intensivetiming induction. A comparison was done with 62 de-novo MDS and 898 de-novo AML children. T-AML/MDS children were older, had lower white blood cell counts and more often MDS ( $21 \%$ vs $7 \%)$ and trisomy. None of the patients had the classic $\mathrm{t}(8 ; 21), \mathrm{t}(15 ; 17)$ and $16 \mathrm{q} 22$ anomalies. Patients were randomized for time- and G-CSF- intensification of therapy. Induction rate comparing t-AML/MDS with de-novo AML was lower $50 \%$ vs $72 \%$, overall survival was $26 \%$ vs $47 \%$ at 3 years), and event-free survival was $21 \%$ vs $39 \%$ at 3 years. $\mathrm{T}-\mathrm{AML} / \mathrm{MDS}$ children who received intensive-timing induction 
had a trend for a better outcomes than those who received standard-timing induction, but this was not significant (overall survival $32 \%$ vs $0 \%, P=0.54$ ). The authors state that most chil-dren with t-AML/MDS have disease resistant to current therapies. Unfortunately they only did univariate analysis and did not correct for specific risk factors [26].

\section{Therapy}

Patients with t-AML have generally a poor tolerance for standard chemotherapy. Generally it is stated that patients with t-AML who have a good performance status should be treated similar as patients with de-novo AML. For those patients who have favorable cytogenetic abnormalities, such as $\mathrm{t}(15 ; 17)$, inv(16), and $\mathrm{t}(8 ; 21)$; intensive chemotherapy is advocated. Hematopoietic stem cell transplantation is advised for unfavorable karyotypes. Supportive care alone may be warranted for those with poor performance status $[21,29,98,99]$. Recently the European Group for Bone Marrow Transplantation and the Center for International Bone Marrow Transplantation Research devised scores to predict outcome including age, cytogenetics, disease status at transplantation and donor characteristics (Tables 2 and 3) [22,115]. The German Alliance Leukemia Study Group devised a similar scoring, but incorporated NPM1 as additional factor and platelet count (Table 4) [116]. EFS and OS were, however, quite different applying these scores. Based on these scoring the treatment advises per subgroup can be formulated as mentioned above.

However, whether these scorings are useful in children is doubtful considering the better tolerance of chemotherapy and less co-morbidity in children as compared to adults and the inclusion of age as risk factor in these scorings It is has been stated that most children with t-AML/MDS have disease resistant to current therapies and all should be classified as high-risk patients. This might not be fully appropriate as the advised is based on univariate analysis only and did not correct for specific risk factors [26]. Since epipodophyllotoxin induced $\mathrm{t}-\mathrm{AML} / \mathrm{MDS}$ is the most common form of $\mathrm{t}-\mathrm{AML} / \mathrm{MDS}$

Table 3. Center for International Bone Marrow Transplantation Research risk scoring for t-AML/MDS (Litzow et al.,).

\begin{tabular}{ll}
\hline Risk factor & Each valid 1 point \\
\hline Age & $>35$ year \\
Poor risk & AML: del $(5 \mathrm{q}) / 25,27 / \operatorname{del}(7 \mathrm{q})$, abn $3 \mathrm{q}, 9 \mathrm{q}, 11 \mathrm{q}, 20 \mathrm{q}$, \\
cytogenetics & $21 \mathrm{q}, 17 \mathrm{p}, \mathrm{t}(6 ; 9), \mathrm{t}(9 ; 22)$ and complex karyotypes \\
& $\begin{array}{l}\geq 3 \text { unrelated abn }) \\
\text { MDS: complex (ie, } \geq 3 \text { anomalies) or chromosome }\end{array}$ \\
& 7 abnormalities \\
Disease state & Not in remission at moment of grafting \\
Donor type & Non-sibling related donor and mismatched donor \\
\hline Risk group & Overall survival (5 year) \\
\hline No risk factors & $50 \%$ \\
1 factor & $26 \%$ \\
2 factors & $21 \%$ \\
3 factors & $10 \%$ \\
4 factors & $5 \%$ \\
\hline
\end{tabular}

Table 4. German alliance leukemia study group (Stölzel et al.,).

\begin{tabular}{lll}
\hline Risk factor & \multicolumn{2}{c}{ Number of points } \\
\hline Age $>60$ years & \multicolumn{2}{c}{1} \\
High risk karyotype & \multicolumn{2}{c}{1} \\
NPM1 wild-type in bone marrow & \multicolumn{2}{c}{1} \\
Platelet count $<50 \times 10^{9} / 1$ in peripheral blood & \multicolumn{2}{c}{1} \\
\hline Risk group & Overall & Event free \\
& survival & survival \\
& (2 year) & $(2$ year) \\
\hline Favorable (0-1 factors) & $58 \%$ & $40 \%$ \\
intermediate (2 factors) & $28 \%$ & $21 \%$ \\
High-risk (3-4 factors) & $9 \%$ & $7 \%$ \\
\hline
\end{tabular}

in childhood. For the cases expressing 11q and 22p anomalies this statement is in line with data from adults. However, for those with APL and inv(16) such an advise cannot be given since no or very low numbers of APL and inv(16) cases were among the patients with $\mathrm{t}-\mathrm{AML} / \mathrm{MDS}$ and the advice is not in line with recommendations in adults. In children the general rule not to transplant patients with APL can be adopted, as it is based on the finding that cell characteristics and outcome in this subgroup is similar to de-novo APL $[21,95,130]$. For non-APL patients with low-risk t-AML/MDS pediatric patients treatment advises could align with advices in adults. As such the presented algorithm can be applied in choosing treatment (Figure 1). Those with unfavorable karyotypes should be transplanted; preferably (if feasible) after bringing them in remission. Those with favorable karyotypes (e.g., $\mathrm{t}(15: 17), \mathrm{t}(8 ; 21)$ and inv (16)) could be treated according protocols similar to de-novo AML protocols. Current new protocols use minimal residual disease (MRD) as surrogate marker for resistant disease and adapt treatment accordingly. As a result some children with t-AML/MDS with good risk characteristics will be transplanted in the end. For some transplantation can be withheld. Only a few patients will be sorted in the supportive care category, since physical condition in children is usually better as compared to adults.

\section{Conclusion}

The incidence of treatment related AML/MDS (t-AML/MDS) in children is extremely low. Consequently assessment of data from adults and to some extent extrapolation from adults is needed. Epipodophyllotoxin induced t-AML/MDS is more common in children, which is likely to be related to the shorter latency period to develop this condition. I FAB-M4, FAB-M5, APL, balanced karyotypes, 11q23 and 21q22 anomalies, inv (16) and $t(15 ; 17)$ are noted more often. Duration and short interval between administrations of epipodophyllotoxins in children results in a higher incidence of t-AML/MDS. Genetic (karyotypic) make up is influencing duration of remission, although the relation with overall-survival is less clear. Choice of therapy should be based on co-morbidity and the 
Henk Van Den Berg, Hematology and Leukemia 2014,

http://www.hoajonline.com/journals/pdf/2052-434X-2-3.pdf

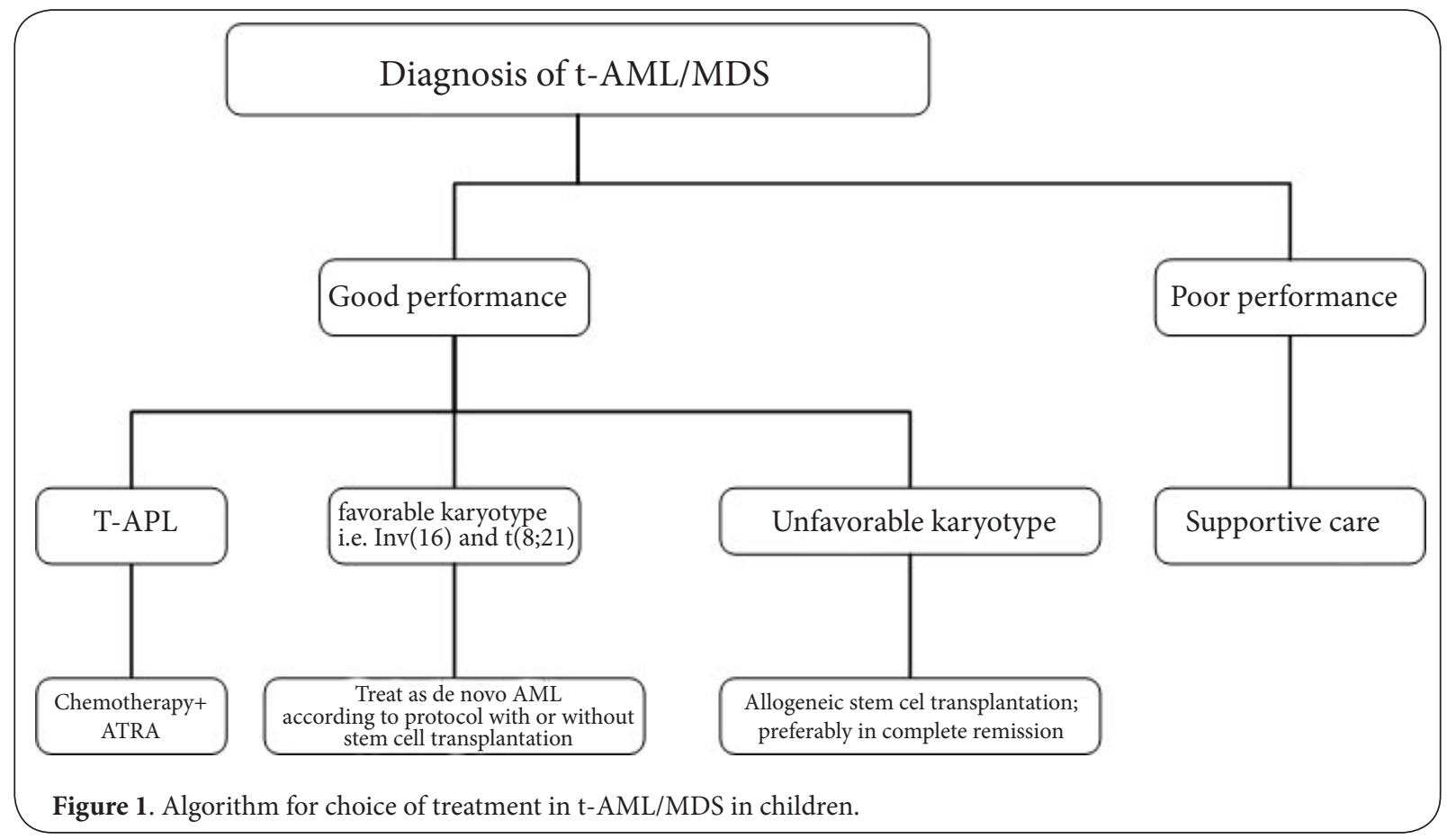

likelihood to undergo intensive therapy. The majority of children with $\mathrm{t}-\mathrm{AML} / \mathrm{MDS}$ should have hematopoietic stem cell transplantation. A minority of children with $\mathrm{t}-\mathrm{AML}$ with $\operatorname{inv}(16), \mathrm{t}(8 ; 21)$ and $\mathrm{t}(15 ; 19)$ translocation should be considered for chemotherapy according to de-novo AML protocols. Monitoring of early response criteria for detection of primary resistance is advised.

\section{Competing interests}

The author declares that he has no competing interests.

\section{Publication history}

Editor: Mingjiang Xu, Indiana University School of Medicine, USA. EIC: Evangelos Terpos, University of Athens School of Medicine, UK. Received: 20-Mar-2014 Final Revised: 19-Apr-2014 Accepted: 25-Apr-2014 Published: 09-May-2014

\section{References}

1. Vardiman JW, Harris NL and Brunning RD. The World Health Organization (WHO) classification of the myeloid neoplasms. Blood. 2002; 100:2292-302. | Article | PubMed

2. Coso D, Costello R, Cohen-Valensi R, Sainty D, Nezri M, Gastaut JA and Bouabdallah R. Acute myeloid leukemia and myelodysplasia in patients with chronic lymphocytic leukemia receiving fludarabine as initial therapy. Ann Oncol. 1999; 10:362-3. | Article | PubMed

3. Martin-Salces M, Canales MA, de Paz R and Hernandez-Navarro F. Treatment-related acute myeloid leukemia with 11 q23 translocation following treatment with fludarabine, cyclophosphamide and rituximab. Leuk Res. 2008; 32:199-200. | Article | PubMed

4. McLaughlin P, Estey E, Glassman A, Romaguera J, Samaniego F, Ayala A, Hayes K, Maddox AM, Preti HA and Hagemeister FB. Myelodysplasia and acute myeloid leukemia following therapy for indolent lymphoma with fludarabine, mitoxantrone, and dexamethasone (FND) plus rituximab and interferon alpha. Blood. 2005; 105:4573-5. | Article | PubMed Abstract | PubMed Full Text
5. Morrison VA, Rai KR, Peterson BL, Kolitz JE, Elias L, Appelbaum FR, Hines JD, Shepherd L, Larson RA and Schiffer CA. Therapyrelated myeloid leukemias are observed in patients with chronic lymphocytic leukemia after treatment with fludarabine and chlorambucil: results of an intergroup study, cancer and leukemia group B 9011. J Clin Oncol. 2002; 20:3878-84. | Article | PubMed

6. Schroeder T, Kuendgen A, Kayser S, Kroger N, Braulke F, Platzbecker U, Klarner V, Zohren F, Haase D, Stadler M, Schlenk R, Czibere AG, Bruns I, Fenk R, Gattermann N, Haas R, Kobbe G and Germing U. Therapyrelated myeloid neoplasms following treatment with radioiodine. Haematologica. 2012; 97:206-12. | Article | PubMed Abstract | PubMed Full Text

7. Offman J, Opelz G, Doehler B, Cummins D, Halil O, Banner NR, Burke MM, Sullivan D, Macpherson P and Karran P. Defective DNA mismatch repair in acute myeloid leukemia/myelodysplastic syndrome after organ transplantation. Blood. 2004; 104:822-8. | Article | PubMed

8. Sill H, Olipitz W, Zebisch A, Schulz E and Wolfler A. Therapy-related myeloid neoplasms: pathobiology and clinical characteristics. $\mathrm{Br}$ J Pharmacol. 2011; 162:792-805. | Article | PubMed Abstract | PubMed Full Text

9. Sandoval C, Pui $\mathrm{CH}$, Bowman LC, Heaton D, Hurwitz CA, Raimondi SC, Behm FG and Head DR. Secondary acute myeloid leukemia in children previously treated with alkylating agents, intercalating topoisomerase II inhibitors, and irradiation. J Clin Oncol. 1993; 11:1039-45. | Article | PubMed

10. Schoch C, Kern W, Schnittger S, Hiddemann W and Haferlach T. Karyotype is an independent prognostic parameter in therapyrelated acute myeloid leukemia (t-AML): an analysis of 93 patients with t-AML in comparison to 1091 patients with de novo AML. Leukemia. 2004; 18:120-5. | Article | PubMed

11. Mauritzson N, Albin M, Rylander L, Billstrom R, Ahlgren T, Mikoczy Z, Bjork J, Stromberg U, Nilsson PG, Mitelman F, Hagmar L and Johansson B. Pooled analysis of clinical and cytogenetic features in treatment-related and de novo adult acute myeloid leukemia and myelodysplastic syndromes based on a consecutive series of 761 patients analyzed 1976-1993 and on 5098 unselected cases reported in the literature 1974-2001. Leukemia. 2002; 16:2366-78. | Article | PubMed

12. Schmiegelow K, Levinsen MF, Attarbaschi A, Baruchel A, Devidas 
Henk Van Den Berg, Hematology and Leukemia 2014,

M, Escherich G, Gibson B, Heydrich C, Horibe K, Ishida Y, Liang DC, Locatelli F, Michel G, Pieters R, Piette C, Pui CH, Raimondi S, Silverman L, Stanulla M, Stark B, Winick N and Valsecchi MG. Second malignant neoplasms after treatment of childhood acute lymphoblastic leukemia. J Clin Oncol. 2013; 31:2469-76. | Article | PubMed

13. Danner-Koptik KE, Majhail NS, Brazauskas R, Wang Z, Buchbinder D, Cahn JY, Dilley KJ, Frangoul HA, Gross TG, Hale GA, Hayashi RJ, Hijiya N, Kamble RT, Lazarus HM, Marks DI, Reddy V, Savani BN, Warwick $A B$, Wingard JR, Wood WA, Sorror ML and Jacobsohn DA. Second malignancies after autologous hematopoietic cell transplantation in children. Bone Marrow Transplant. 2013; 48:363-8. | Article | PubMed Abstract I PubMed Full Text

14. Friedman DL, Whitton J, Leisenring W, Mertens AC, Hammond S, Stovall M, Donaldson SS, Meadows AT, Robison LL and Neglia JP. Subsequent neoplasms in 5-year survivors of childhood cancer: the Childhood Cancer Survivor Study. J Natl Cancer Inst. 2010; 102:1083-95. I Article | PubMed Abstract | PubMed Full Text

15. Hijiya N, Ness KK, Ribeiro RC and Hudson MM. Acute leukemia as a secondary malignancy in children and adolescents: current findings and issues. Cancer. 2009; 115:23-35. | Article | PubMed Abstract | PubMed Full Text

16. Cardous-Ubbink MC, Heinen RC, Langeveld NE, Bakker PJ, Voute PA, Caron HN and van Leeuwen FE. Long-term cause-specific mortality among five-year survivors of childhood cancer. Pediatr Blood Cancer. 2004; 42:563-73. | Article | PubMed

17. Cardous-Ubbink MC, Heinen RC, Bakker PJ, van den Berg H, Oldenburger F, Caron HN, Voute PA and van Leeuwen FE. Risk of second malignancies in long-term survivors of childhood cancer. Eur J Cancer. 2007; 43:351-62. | Article | PubMed

18. Walter MJ, Shen D, Ding L, Shao J, Koboldt DC, Chen K, Larson DE, McLellan MD, Dooling D, Abbott R, Fulton R, Magrini V, Schmidt $H$, Kalicki-Veizer J, O'Laughlin M, Fan X, Grillot M, Witowski S, Heath S, Frater JL, Eades W, Tomasson M, Westervelt P, DiPersio JF, Link DC, Mardis ER, Ley TJ, Wilson RK and Graubert TA. Clonal architecture of secondary acute myeloid leukemia. N Engl J Med. 2012; 366:1090-8. | Article | PubMed Abstract | PubMed Full Text

19. Greene MH, Harris EL, Gershenson DM, Malkasian GD, Jr., Melton LJ, 3rd, Dembo AJ, Bennett JM, Moloney WC and Boice JD, Jr. Melphalan may be a more potent leukemogen than cyclophosphamide. Ann Intern Med. 1986; 105:360-7. | Article | PubMed

20. Curtis RE, Boice JD, Jr., Stovall M, Bernstein L, Greenberg RS, Flannery JT, Schwartz AG, Weyer P, Moloney WC and Hoover RN. Risk of leukemia after chemotherapy and radiation treatment for breast cancer. N Engl J Med. 1992; 326:1745-51. | Article | PubMed

21. Godley LA and Larson RA. Therapy-related myeloid leukemia. Semin Oncol. 2008; 35:418-29. | Article | PubMed Abstract | PubMed Full Text

22. Kroger N, Brand R, van Biezen A, Zander A, Dierlamm J, Niederwieser D, Devergie A, Ruutu T, Cornish J, Ljungman P, Gratwohl A, Cordonnier C, Beelen D, Deconinck E, Symeonidis A and de Witte T. Risk factors for therapy-related myelodysplastic syndrome and acute myeloid leukemia treated with allogeneic stem cell transplantation. Haematologica. 2009; 94:542-9. | Article | PubMed Abstract | PubMed Full Text

23. Duffield AS, Aoki J, Levis M, Cowan K, Gocke CD, Burns KH, Borowitz MJ and Vuica-Ross M. Clinical and pathologic features of secondary acute promyelocytic leukemia. Am J Clin Pathol. 2012; 137:395-402. | Article | PubMed Abstract | PubMed Full Text

24. Huh HJ, Lee SH, Yoo KH, Sung KW, Koo HH, Kim K, Jang JH, Jung C, Kim $\mathrm{SH}$ and Kim HJ. Therapy-related myeloid neoplasms in 39 Korean patients: a single institution experience. Ann Lab Med. 2013; 33:97104. | Article | PubMed Abstract | PubMed Full Text

25. Pui CH, Relling MV, Rivera GK, Hancock ML, Raimondi SC, Heslop $\mathrm{HE}$, Santana VM, Ribeiro RC, Sandlund JT, Mahmoud HH and et al. Epipodophyllotoxin-related acute myeloid leukemia: a study of $\mathbf{3 5}$ cases. Leukemia. 1995; 9:1990-6. | Article | PubMed

26. Barnard DR, Lange B, Alonzo TA, Buckley J, Kobrinsky JN, Gold S, Neudorf S, Sanders J, Burden L and Woods WG. Acute myeloid leukemia and myelodysplastic syndrome in children treated for cancer: comparison with primary presentation. Blood. 2002; 100:427-
34. | Article | PubMed

27. Smith SM, Le Beau MM, Huo D, Karrison T, Sobecks RM, Anastasi J, Vardiman JW, Rowley JD and Larson RA. Clinical-cytogenetic associations in $\mathbf{3 0 6}$ patients with therapy-related myelodysplasia and myeloid leukemia: the University of Chicago series. Blood. 2003; 102:43-52. | Article | PubMed

28. Larson RA, Wang Y, Banerjee M, Wiemels J, Hartford C, Le Beau MM and Smith MT. Prevalence of the inactivating 609C-->T polymorphism in the $\mathrm{NAD}(\mathrm{P}) \mathrm{H}$ :quinone oxidoreductase (NQO1) gene in patients with primary and therapy-related myeloid leukemia. Blood. 1999; 94:803-7. | Article | PubMed

29. Larson RA. Etiology and management of therapy-related myeloid leukemia. Hematology Am Soc Hematol Educ Program. 2007; 453-9. I Article | PubMed

30. Knight JA, Skol AD, Shinde A, Hastings D, Walgren RA, Shao J, Tennant TR, Banerjee M, Allan JM, Le Beau MM, Larson RA, Graubert TA, Cox $\mathrm{NJ}$ and Onel K. Genome-wide association study to identify novel loci associated with therapy-related myeloid leukemia susceptibility. Blood. 2009; 113:5575-82. | Article | PubMed Abstract | PubMed Full Text

31. Pedersen-Bjergaard J, Andersen MK and Johansson B. Balanced chromosome aberrations in leukemias following chemotherapy with DNA-topoisomerase II inhibitors. J Clin Oncol. 1998; 16:1897-8. | Article I PubMed

32. Pedersen-Bjergaard J and Rowley JD. The balanced and the unbalanced chromosome aberrations of acute myeloid leukemia may develop in different ways and may contribute differently to malignant transformation. Blood. 1994; 83:2780-6. | Article | PubMed

33. Pedersen-Bjergaard J, Philip P, Larsen SO, Andersson M, Daugaard G, Ersboll J, Hansen SW, Hou-Jensen K, Nielsen D, Sigsgaard TC and et al. Therapy-related myelodysplasia and acute myeloid leukemia. Cytogenetic characteristics of 115 consecutive cases and risk in seven cohorts of patients treated intensively for malignant diseases in the Copenhagen series. Leukemia. 1993; 7:1975-86. | Article | PubMed

34. Pedersen-Bjergaard J, Pedersen M, Roulston D and Philip P. Different genetic pathways in leukemogenesis for patients presenting with therapy-related myelodysplasia and therapy-related acute myeloid leukemia. Blood. 1995; 86:3542-52. | Article | PubMed

35. Secker-Walker LM, Moorman AV, Bain BJ and Mehta AB. Secondary acute leukemia and myelodysplastic syndrome with 11q23 abnormalities. EU Concerted Action 11q23 Workshop. Leukemia. 1998; 12:840-4. | PubMed

36. Leone G, Mele L, Pulsoni A, Equitani F and Pagano L. The incidence of secondary leukemias. Haematologica. 1999; 84:937-45. | Article | PubMed

37. Pui CH, Relling MV, Behm FG, Hancock ML, Boyett JM, Raimondi SC, Krance RA, Mahmoud HH, Ribeiro RC, Sandlund JT and et al. L-asparaginase may potentiate the leukemogenic effect of the epipodophyllotoxins. Leukemia. 1995; 9:1680-4. | Article | PubMed

38. Felix CA. Secondary leukemias induced by topoisomerase-targeted drugs. Biochim Biophys Acta. 1998; 1400:233-55. | Article I PubMed

39. Ellis $M$, Ravid $M$ and Lishner $M$. A comparative analysis of alkylating agent and epipodophyllotoxin-related leukemias. Leuk Lymphoma. 1993; 11:9-13. | Article | PubMed

40. Rubin CM, Arthur DC, Woods WG, Lange BJ, Nowell PC, Rowley JD, Nachman J, Bostrom B, Baum ES, Suarez CR and et al. Therapy-related myelodysplastic syndrome and acute myeloid leukemia in children: correlation between chromosomal abnormalities and prior therapy. Blood. 1991; 78:2982-8. | Article | PubMed

41. Pedersen-Bjergaard J, Christiansen DH, Desta F and Andersen MK. Alternative genetic pathways and cooperating genetic abnormalities in the pathogenesis of therapy-related myelodysplasia and acute myeloid leukemia. Leukemia. 2006; 20:1943-9. | Article | PubMed

42. Rinsky RA. Benzene and leukemia: an epidemiologic risk assessment. Environ Health Perspect. 1989; 82:189-91. | PubMed Abstract | PubMed Full Text

43. Bhatia S, Robison LL, Oberlin O, Greenberg M, Bunin G, Fossati-Bellani $\mathrm{F}$ and Meadows AT. Breast cancer and other second neoplasms after childhood Hodgkin's disease. N Engl J Med. 1996; 334:745-51. | Article I PubMed 
Henk Van Den Berg, Hematology and Leukemia 2014,

44. Schellong G, Riepenhausen M, Creutzig U, Ritter J, Harbott J, Mann G and Gadner H. Low risk of secondary leukemias after chemotherapy without mechlorethamine in childhood Hodgkin's disease. GermanAustrian Pediatric Hodgkin's Disease Group. J Clin Oncol. 1997; 15:2247-53. | Article | PubMed

45. Cimino G, Papa G, Tura S, Mazza P, Rossi Ferrini PL, Bosi A, Amadori S, Lo Coco F, D’Arcangelo E, Giannarelli D and et al. Second primary cancer following Hodgkin's disease: updated results of an Italian multicentric study. J Clin Oncol. 1991; 9:432-7. I Article I PubMed

46. Brusamolino E, Gotti M and Fiaccadori V. The Risk of Therapy-Related Myelodysplasia/Acute Myeloid Leukemia in Hodgkin Lymphoma has Substantially Decreased in the ABVD Era Abolishing Mechlorethamine and Procarbazine and Limiting Volumes and Doses of Radiotherapy. Mediterr J Hematol Infect Dis. 2012; 4:e2012022. | Article | PubMed Abstract I PubMed Full Text

47. Koontz MZ, Horning SJ, Balise R, Greenberg PL, Rosenberg SA, Hoppe $\mathrm{RT}$ and Advani RH. Risk of therapy-related secondary leukemia in Hodgkin lymphoma: the Stanford University experience over three generations of clinical trials. J Clin Oncol. 2013; 31:592-8. I Article I PubMed Abstract | PubMed Full Text

48. Ratain MJ, Kaminer LS, Bitran JD, Larson RA, Le Beau MM, Skosey C, Purl S, Hoffman PC, Wade J, Vardiman JW and et al. Acute nonlymphocytic leukemia following etoposide and cisplatin combination chemotherapy for advanced non-small-cell carcinoma of the lung. Blood. 1987; 70:1412-7. | Article | PubMed

49. Le Deley MC, Leblanc T, Shamsaldin A, Raquin MA, Lacour B, Sommelet D, Chompret A, Cayuela JM, Bayle C, Bernheim A, de Vathaire F, Vassal $\mathrm{G}$ and Hill C. Risk of secondary leukemia after a solid tumor in childhood according to the dose of epipodophyllotoxins and anthracyclines: a case-control study by the Societe Francaise d’Oncologie Pediatrique. J Clin Oncol. 2003; 21:1074-81. | Article | PubMed

50. Smith MA, Rubinstein L, Anderson JR, Arthur D, Catalano PJ, Freidlin B, Heyn R, Khayat A, Krailo M, Land VJ, Miser J, Shuster J and Vena D. Secondary leukemia or myelodysplastic syndrome after treatment with epipodophyllotoxins. J Clin Oncol. 1999; 17:569-77. | Article | PubMed

51. Pui CH, Ribeiro RC, Hancock ML, Rivera GK, Evans WE, Raimondi SC, Head DR, Behm FG, Mahmoud MH, Sandlund JT and et al. Acute myeloid leukemia in children treated with epipodophyllotoxins for acute lymphoblastic leukemia. N Engl J Med. 1991; 325:1682-7. | Article | PubMed

52. Le Deley MC, Suzan F, Cutuli B, Delaloge S, Shamsaldin A, Linassier C, Clisant S, de Vathaire F, Fenaux P and Hill C. Anthracyclines, mitoxantrone, radiotherapy, and granulocyte colony-stimulating factor: risk factors for leukemia and myelodysplastic syndrome after breast cancer. J Clin Oncol. 2007; 25:292-300. | Article | PubMed

53. Saso R, Kulkarni S, Mitchell P, Treleaven J, Swansbury GJ, Mehta J, Powles R, Ashley S, Kuan A and Powles T. Secondary myelodysplastic syndrome/acute myeloid leukaemia following mitoxantrone-based therapy for breast carcinoma. Br J Cancer. 2000; 83:91-4. | Article | PubMed Abstract | PubMed Full Text

54. Linassier C, Barin C, Calais G, Letortorec S, Bremond JL, Delain M, Petit A, Georget MT, Cartron G, Raban N, Benboubker L, Leloup R, Binet C Lamagnere JP and Colombat $P$. Early secondary acute myelogenous leukemia in breast cancer patients after treatment with mitoxantrone, cyclophosphamide, fluorouracil and radiation therapy. Ann Oncol. 2000; 11:1289-94. | Article | PubMed

55. Chaplain G, Milan C, Sgro C, Carli PM and Bonithon-Kopp C. Increased risk of acute leukemia after adjuvant chemotherapy for breast cancer: a population-based study. J Clin Oncol. 2000; 18:2836-42. | Article | PubMed

56. Smith MA, McCaffrey RP and Karp JE. The secondary leukemias: challenges and research directions. J Natl Cancer Inst. 1996; 88:40718. | Article | PubMed

57. Samet JM. Epidemiologic studies of ionizing radiation and cancer: past successes and future challenges. Environ Health Perspect. 1997; 105 Suppl 4:883-9. | PubMed Abstract | PubMed Full Text

58. Kantarjian HM, Keating MJ, Walters RS, Smith TL, Cork A, McCredie
KB and Freireich EJ. Therapy-related leukemia and myelodysplastic syndrome: clinical, cytogenetic, and prognostic features. J Clin Oncol. 1986; 4:1748-57. | Article | PubMed

59. Davies SM. Therapy-related leukemia associated with alkylating agents. Med Pediatr Oncol. 2001; 36:536-40. | Article | PubMed

60. Mahgoub N, Taylor BR, Le Beau MM, Gratiot M, Carlson KM, Atwater SK, Jacks T and Shannon KM. Myeloid malignancies induced by alkylating agents in Nf1 mice. Blood. 1999; 93:3617-23. | Article PubMed

61. Chen H, Sandler DP, Taylor JA, Shore DL, Liu E, Bloomfield CD and Bell DA. Increased risk for myelodysplastic syndromes in individuals with glutathione transferase theta 1 (GSTT1) gene defect. Lancet. 1996; 347:295-7. | Article | PubMed

62. Amylon MD, Shuster J, Pullen J, Berard C, Link MP, Wharam M, Katz J, Yu A, Laver J, Ravindranath Y, Kurtzberg J, Desai S, Camitta B and Murphy SB. Intensive high-dose asparaginase consolidation improves survival for pediatric patients with $\mathrm{T}$ cell acute lymphoblastic leukemia and advanced stage lymphoblastic lymphoma: a Pediatric Oncology Group study. Leukemia. 1999; 13:335-42. I Article I PubMed

63. Kushner BH, Cheung NK, Kramer K, Heller G and Jhanwar SC. Neuroblastoma and treatment-related myelodysplasia/leukemia: the Memorial Sloan-Kettering experience and a literature review. J Clin Oncol. 1998; 16:3880-9. | Article | PubMed

64. Hershman D, Neugut Al, Jacobson JS, Wang J, Tsai WY, McBride R, Bennett $\mathrm{CL}$ and Grann VR. Acute myeloid leukemia or myelodysplastic syndrome following use of granulocyte colony-stimulating factors during breast cancer adjuvant chemotherapy. J Natl Cancer Inst. 2007; 99:196-205. | Article I PubMed

65. Patt DA, Duan Z, Fang S, Hortobagyi GN and Giordano SH. Acute myeloid leukemia after adjuvant breast cancer therapy in older women: understanding risk. J Clin Oncol. 2007; 25:3871-6. | Article | PubMed

66. Bhatia S. Role of genetic susceptibility in development of treatmentrelated adverse outcomes in cancer survivors. Cancer Epidemiol Biomarkers Prev. 2011; 20:2048-67. | Article | PubMed Abstract | PubMed Full Text

67. Relling MV, Boyett JM, Blanco JG, Raimondi S, Behm FG, Sandlund JT, Rivera GK, Kun LE, Evans WE and Pui CH. Granulocyte colonystimulating factor and the risk of secondary myeloid malignancy after etoposide treatment. Blood. 2003; 101:3862-7. I Article I PubMed

68. Lyman GH, Dale DC, Wolff DA, Culakova E, Poniewierski MS, Kuderer NM and Crawford J. Acute myeloid leukemia or myelodysplastic syndrome in randomized controlled clinical trials of cancer chemotherapy with granulocyte colony-stimulating factor: a systematic review. J Clin Oncol. 2010; 28:2914-24. I Article I PubMed Abstract I PubMed Full Text

69. van Dalen EC, van den Berg $\mathrm{H}$, Raphael MF, Caron HN and Kremer LC. Should anthracyclines and dexrazoxane be used for children with cancer? Lancet Oncol. 2011; 12:12-3. | Article | PubMed

70. Tebbi CK, London WB, Friedman D, Villaluna D, De Alarcon PA, Constine LS, Mendenhall NP, Sposto R, Chauvenet A and Schwartz $\mathrm{CL}$. Dexrazoxane-associated risk for acute myeloid leukemia/ myelodysplastic syndrome and other secondary malignancies in pediatric Hodgkin's disease. J Clin Oncol. 2007; 25:493-500. I Article | PubMed

71. Barry EV, Vrooman LM, Dahlberg SE, Neuberg DS, Asselin BL, Athale UH, Clavell LA, Larsen EC, Moghrabi A, Samson Y, Schorin MA, Cohen HJ, Lipshultz SE, Sallan SE and Silverman LB. Absence of secondary malignant neoplasms in children with high-risk acute lymphoblastic leukemia treated with dexrazoxane. J Clin Oncol. 2008; 26:1106-11. I Article | PubMed

72. Micallef IN, Lillington DM, Apostolidis J, Amess JA, Neat M, Matthews J, Clark T, Foran JM, Salam A, Lister TA and Rohatiner AZ. Therapy-related myelodysplasia and secondary acute myelogenous leukemia after high-dose therapy with autologous hematopoietic progenitor-cell support for lymphoid malignancies. J Clin Oncol. 2000; 18:947-55. Article I PubMed

73. Lenz G, Dreyling M, Schiegnitz E, Haferlach T, Hasford J, Unterhalt M and Hiddemann W. Moderate increase of secondary hematologic 
malignancies after myeloablative radiochemotherapy and autologous stem-cell transplantation in patients with indolent lymphoma: results of a prospective randomized trial of the German Low Grade Lymphoma Study Group. J Clin Oncol. 2004; 22:4926-33. | Article | PubMed

74. Krishnan A, Bhatia S, Slovak ML, Arber DA, Niland JC, Nademanee A, Fung H, Bhatia R, Kashyap A, Molina A, O'Donnell MR, Parker PA, Sniecinski I, Snyder DS, Spielberger R, Stein A and Forman SJ. Predictors of therapy-related leukemia and myelodysplasia following autologous transplantation for lymphoma: an assessment of risk factors. Blood. 2000; 95:1588-93. | Article | PubMed

75. Hake CR, Graubert TA and Fenske TS. Does autologous transplantation directly increase the risk of secondary leukemia in lymphoma patients? Bone Marrow Transplant. 2007; 39:59-70. | Article | PubMed

76. Felix CA. Leukemias related to treatment with DNA topoisomerase II inhibitors. Med Pediatr Oncol. 2001; 36:525-35. | Article | PubMed

77. Relling MV, Yanishevski Y, Nemec J, Evans WE, Boyett JM, Behm FG and Pui CH. Etoposide and antimetabolite pharmacology in patients who develop secondary acute myeloid leukemia. Leukemia. 1998; 12:34652. | Article | PubMed

78. Leone G, Pagano L, Ben-Yehuda D and Voso MT. Therapy-related leukemia and myelodysplasia: susceptibility and incidence. Haematologica. 2007; 92:1389-98. | Article | PubMed

79. Seedhouse C, Faulkner R, Ashraf N, Das-Gupta E and Russell N. Polymorphisms in genes involved in homologous recombination repair interact to increase the risk of developing acute myeloid leukemia. Clin Cancer Res. 2004; 10:2675-80. | Article | PubMed

80. Allan JM, Wild CP, Rollinson S, Willett EV, Moorman AV, Dovey GJ, Roddam PL, Roman E, Cartwright RA and Morgan GJ. Polymorphism in glutathione S-transferase $\mathbf{P 1}$ is associated with susceptibility to chemotherapy-induced leukemia. Proc Natl Acad Sci U S A. 2001; 98:11592-7. | Article | PubMed Abstract | PubMed Full Text

81. Sheikhha MH, Tobal K and Liu Yin JA. High level of microsatellite instability but not hypermethylation of mismatch repair genes in therapy-related and secondary acute myeloid leukaemia and myelodysplastic syndrome. Br J Haematol. 2002; 117:359-65. | Article | PubMed

82. Seedhouse $C$ and Russell $N$. Advances in the understanding of susceptibility to treatment-related acute myeloid leukaemia. $\mathrm{Br} J$ Haematol. 2007; 137:513-29. | Article | PubMed

83. Naoe T, Takeyama K, Yokozawa T, Kiyoi H, Seto M, Uike N, Ino T, Utsunomiya A, Maruta A, Jin-nai I, Kamada N, Kubota Y, Nakamura H, Shimazaki C, Horiike S, Kodera Y, Saito H, Ueda R, Wiemels J and Ohno R. Analysis of genetic polymorphism in NQO1, GST-M1, GST-T1, and CYP3A4 in 469 Japanese patients with therapy-related leukemia/ myelodysplastic syndrome and de novo acute myeloid leukemia. Clin Cancer Res. 2000; 6:4091-5. | Article | PubMed

84. Worrillow LJ, Travis LB, Smith AG, Rollinson S, Smith AJ, Wild CP, Holowaty EJ, Kohler BA, Wiklund T, Pukkala E, Roman E, Morgan GJ and Allan JM. An intron splice acceptor polymorphism in $\mathrm{hMSH} 2$ and risk of leukemia after treatment with chemotherapeutic alkylating agents. Clin Cancer Res. 2003; 9:3012-20. I Article I PubMed

85. Fern L, Pallis $M$, lan Carter $G$, Seedhouse $C$, Russell $N$ and Byrne J. Clonal haemopoiesis may occur after conventional chemotherapy and is associated with accelerated telomere shortening and defects in the NQO1 pathway; possible mechanisms leading to an increased risk of t-AML/MDS. Br J Haematol. 2004; 126:63-71. | Article | PubMed

86. Bolufer $\mathrm{P}$, Collado M, Barragan E, Calasanz MJ, Colomer D, Tormo M, Gonzalez M, Brunet S, Batlle M, Cervera J and Sanz MA. Profile of polymorphisms of drug-metabolising enzymes and the risk of therapy-related leukaemia. Br J Haematol. 2007; 136:590-6. | Article I PubMed

87. Guillem VM, Collado M, Terol MJ, Calasanz MJ, Esteve J, Gonzalez M, Sanzo C, Nomdedeu J, Bolufer P, Lluch A and Tormo M. Role of MTHFR $(677,1298)$ haplotype in the risk of developing secondary leukemia after treatment of breast cancer and hematological malignancies. Leukemia. 2007; 21:1413-22. | Article | PubMed

88. Zebisch A, Czernilofsky AP, Keri G, Smigelskaite J, Sill H and Troppmair J. Signaling through RAS-RAF-MEK-ERK: from basics to bedside. Curr
Med Chem. 2007; 14:601-23. | Article | PubMed

89. Hasle H. Pattern of malignant disorders in individuals with Down's syndrome. Lancet Oncol. 2001; 2:429-36. | Article | PubMed

90. Mathew CG. Fanconi anaemia genes and susceptibility to cancer. Oncogene. 2006; 25:5875-84. | Article | PubMed

91. Pagana L, Pulsoni A, Tosti ME, Avvisati G, Mele L, Mele M, Martino B, Visani G, Cerri R, Di Bona E, Invernizzi R, Nosari A, Clavio M, Allione B, Coser P, Candoni A, Levis A, Camera A, Melillo L, Leone G and Mandelli F. Clinical and biological features of acute myeloid leukaemia occurring as second malignancy: GIMEMA archive of adult acute leukaemia. Br J Haematol. 2001; 112:109-17. | Article | PubMed

92. Denayer E, de Ravel $\mathrm{T}$ and Legius E. Clinical and molecular aspects of RAS related disorders. J Med Genet. 2008; 45:695-703. | Article | PubMed

93. Li FP, Fraumeni JF, Jr., Mulvihill JJ, Blattner WA, Dreyfus MG, Tucker MA and Miller RW. A cancer family syndrome in twenty-four kindreds. Cancer Res. 1988; 48:5358-62. | Article | PubMed

94. Lauchle JO, Braun BS, Loh ML and Shannon K. Inherited predispositions and hyperactive Ras in myeloid leukemogenesis. Pediatr Blood Cancer. 2006; 46:579-85. | Article | PubMed

95. Beaumont M, Sanz M, Carli PM, Maloisel F, Thomas X, Detourmignies L, Guerci A, Gratecos N, Rayon C, San Miguel J, Odriozola J, Cahn JY, Huguet F, Vekhof A, Stamatoulas A, Dombret H, Capote F, Esteve J, Stoppa AM and Fenaux P. Therapy-related acute promyelocytic leukemia. J Clin Oncol. 2003; 21:2123-37. | Article | PubMed

96. Gombos DS, Hungerford J, Abramson DH, Kingston J, Chantada G, Dunkel IJ, Antoneli CB, Greenwald M, Haik BG, Leal CA, Medina-Sanson A, Schefler AC, Veerakul G, Wieland R, Bornfeld N, Wilson MW and $\mathrm{Yu} C \mathrm{CB}$. Secondary acute myelogenous leukemia in patients with retinoblastoma: is chemotherapy a factor? Ophthalmology. 2007; 114:1378-83. | Article | PubMed

97. Hoyle CF, de Bastos M, Wheatley K, Sherrington PD, Fischer PJ, Rees JK, Gray R and Hayhoe FG. AML associated with previous cytotoxic therapy, MDS or myeloproliferative disorders: results from the MRC's 9th AML trial. Br J Haematol. 1989; 72:45-53. | Article | PubMed

98. Larson RA, Wernli M, Le Beau MM, Daly KM, Pape LH, Rowley JD and Vardiman JW. Short remission durations in therapy-related leukemia despite cytogenetic complete responses to high-dose cytarabine. Blood. 1988; 72:1333-9. | Article | PubMed

99. Kantarjian HM, Estey EH and Keating MJ. Treatment of therapy-related leukemia and myelodysplastic syndrome. Hematol Oncol Clin North Am. 1993; 7:81-107. | Article | PubMed

100. Takeyama K, Seto M, Uike N, Hamajima N, Ino T, Mikuni C, Kobayashi T, Maruta A, Muto Y, Maseki N, Sakamaki H, Saitoh H, Shimoyama M and Ueda R. Therapy-related leukemia and myelodysplastic syndrome: a large-scale Japanese study of clinical and cytogenetic features as well as prognostic factors. Int J Hematol. 2000; 71:144-52. | Article | PubMed

101. Godley LA, Njiaju UO, Green M, Weiner H, Lin S, Odenike O, Rich ES, Artz A, Van Besien K, Daugherty CK, Zhang Y, Le Beau MM, Stock W and Larson RA. Treatment of therapy-related myeloid neoplasms with high-dose cytarabine/mitoxantrone followed by hematopoietic stem cell transplant. Leuk Lymphoma. 2010; 51:995-1006. | Article | PubMed

102. Hale GA, Heslop HE, Bowman LC, Rochester RA, Pui CH, Brenner $\mathrm{MK}$ and Krance RA. Bone marrow transplantation for therapyinduced acute myeloid leukemia in children with previous lymphoid malignancies. Bone Marrow Transplant. 1999; 24:735-9. | Article | PubMed

103. Leahey AM, Friedman DL and Bunin NJ. Bone marrow transplantation in pediatric patients with therapy-related myelodysplasia and leukemia. Bone Marrow Transplant. 1999; 23:21-5. | Article | PubMed

104. Sandler ES, Friedman DJ, Mustafa MM, Winick NJ, Bowman WP and Buchanan GR. Treatment of children with epipodophyllotoxin-induced secondary acute myeloid leukemia. Cancer. 1997; 79:1049-54. | Article | PubMed

105. Tabori U, Revach G, Nathan PC, Strahm B, Rachlis A, Shago M, Grant R, Doyle J and Malkin D. Toxicity and outcome of children with treatment related acute myeloid leukemia. Pediatr Blood Cancer. 2008; 50:17-23. 
Henk Van Den Berg, Hematology and Leukemia 2014,

http://www.hoajonline.com/journals/pdf/2052-434X-2-3.pdf

doi: $10.7243 / 2052-434 \mathrm{X}-2-3$

\section{| Article | PubMed}

106. Michels SD, McKenna RW, Arthur DC and Brunning RD. Therapy-related acute myeloid leukemia and myelodysplastic syndrome: a clinical and morphologic study of 65 cases. Blood. 1985; 65:1364-72. | Article | PubMed

107. Lowenberg B, Downing JR and Burnett A. Acute myeloid leukemia. $N$ Engl J Med. 1999; 341:1051-62. | Article | PubMed

108. Anderson JE, Kopecky KJ, Willman CL, Head D, O'Donnell MR, Luthardt FW, Norwood TH, Chen IM, Balcerzak SP, Johnson DB and Appelbaum FR. Outcome after induction chemotherapy for older patients with acute myeloid leukemia is not improved with mitoxantrone and etoposide compared to cytarabine and daunorubicin: a Southwest Oncology Group study. Blood. 2002; 100:3869-76. | Article | PubMed

109. Ballen KK and Antin JH. Treatment of therapy-related acute myelogenous leukemia and myelodysplastic syndromes. Hematol Oncol Clin North Am. 1993; 7:477-93. I PubMed

110. Greenberg PL, Lee SJ, Advani R, Tallman MS, Sikic BI, Letendre L, Dugan K, Lum B, Chin DL, Dewald G, Paietta E, Bennett JM and Rowe JM. Mitoxantrone, etoposide, and cytarabine with or without valspodar in patients with relapsed or refractory acute myeloid leukemia and highrisk myelodysplastic syndrome: a phase III trial (E2995). J Clin Oncol. 2004; 22:1078-86. | Article | PubMed

111. Godwin JE, Kopecky KJ, Head DR, Willman CL, Leith CP, Hynes HE, Balcerzak SP and Appelbaum FR. A double-blind placebo-controlled trial of granulocyte colony-stimulating factor in elderly patients with previously untreated acute myeloid leukemia: a Southwest oncology group study (9031). Blood. 1998; 91:3607-15. | Article | PubMed

112. Leith CP, Kopecky KJ, Godwin J, McConnell T, Slovak ML, Chen IM, Head $\mathrm{DR}$, Appelbaum FR and Willman CL. Acute myeloid leukemia in the elderly: assessment of multidrug resistance (MDR1) and cytogenetics distinguishes biologic subgroups with remarkably distinct responses to standard chemotherapy. A Southwest Oncology Group study. Blood. 1997; 89:3323-9. | Article | PubMed

113. Steinbach D, Furchtbar S, Sell W, Lengemann J, Hermann J, Zintl F and Sauerbrey A. Contrary to adult patients, expression of the multidrug resistance gene (MDR1) fails to define a poor prognostic group in childhood AML. Leukemia. 2003; 17:470-1. | Article | PubMed

114. Armand P, Kim HT, DeAngelo DJ, Ho VT, Cutler CS, Stone RM, Ritz J, Alyea EP, Antin JH and Soiffer RJ. Impact of cytogenetics on outcome of de novo and therapy-related AML and MDS after allogeneic transplantation. Biol Blood Marrow Transplant. 2007; 13:655-64. | Article I PubMed Abstract I PubMed Full Text

115. Litzow MR, Tarima S, Perez WS, Bolwell BJ, Cairo MS, Camitta BM, Cutler CS, de Lima M, Dipersio JF, Gale RP, Keating A, Lazarus HM, Luger S, Marks DI, Maziarz RT, McCarthy PL, Pasquini MC, Phillips GL, Rizzo JD, Sierra J, Tallman MS and Weisdorf DJ. Allogeneic transplantation for therapy-related myelodysplastic syndrome and acute myeloid leukemia. Blood. 2010; 115:1850-7. | Article | PubMed Abstract | PubMed Full Text

116. Stolzel F, Pfirrmann M, Aulitzky WE, Kaufmann M, Bodenstein $H$, Bornhauser M, Rollig C, Kramer M, Mohr B, Oelschlagel U, Schmitz N, Soucek S, Thiede C, Ehninger G and Schaich M. Risk stratification using a new prognostic score for patients with secondary acute myeloid leukemia: results of the prospective AML96 trial. Leukemia. 2011; 25:420-8. | Article | PubMed

117. Quesnel B, Kantarjian H, Bjergaard JP, Brault P, Estey E, Lai JL, Tilly H, Stoppa AM, Archimbaud E, Harousseau JL and et al. Therapy-related acute myeloid leukemia with $t(8 ; 21)$, inv(16), and $t(8 ; 16)$ : a report on 25 cases and review of the literature. J Clin Oncol. 1993; 11:2370-9. I Article | PubMed

118. Larson RA. Is secondary leukemia an independent poor prognostic factor in acute myeloid leukemia? Best Pract Res Clin Haematol. 2007; 20:29-37. | Article | PubMed

119. Kern W, Haferlach T, Schnittger S, Hiddemann W and Schoch C. Prognosis in therapy-related acute myeloid leukemia and impact of karyotype. J Clin Oncol. 2004; 22:2510-1. | Article I PubMed

120. Park SH, Chi HS, Cho YU, Jang S and Park CJ. Evaluation of prognostic factors in patients with therapy-related acute myeloid leukemia. Blood Res. 2013; 48:185-92. | Article | PubMed Abstract | PubMed Full. $\underline{\text { Text }}$

121. Pulsoni A, Pagano L, Lo Coco F, Avvisati G, Mele L, Di Bona E, Invernizzi R, Leoni F, Marmont F, Mele A, Melillo L, Nosari AM, Pogliani EM, Vignetti M, Visani G, Zagonel V, Leone G and Mandelli F. Clinicobiological features and outcome of acute promyelocytic leukemia occurring as a second tumor: the GIMEMA experience. Blood. 2002; 100:1972-6. | Article | PubMed

122. Kayser S, Dohner K, Krauter J, Kohne CH, Horst HA, Held G, von Lilienfeld-Toal M, Wilhelm S, Kundgen A, Gotze K, Rummel M, Nachbaur D, Schlegelberger B, Gohring G, Spath D, Morlok C, Zucknick M, Ganser $A$, Dohner $H$ and Schlenk RF. The impact of therapy-related acute myeloid leukemia (AML) on outcome in $\mathbf{2 8 5 3}$ adult patients with newly diagnosed AML. Blood. 2011; 117:2137-45. | Article | PubMed

123. Yakoub-Agha I, de La Salmoniere P, Ribaud P, Sutton L, Wattel E, Kuentz M, Jouet JP, Marit G, Milpied N, Deconinck E, Gratecos N, Leporrier M, Chabbert I, Caillot D, Damaj G, Dauriac C, Dreyfus F, Francois S, Molina L, Tanguy ML, Chevret $S$ and Gluckman E. Allogeneic bone marrow transplantation for therapy-related myelodysplastic syndrome and acute myeloid leukemia: a long-term study of 70 patients-report of the French society of bone marrow transplantation. J Clin Oncol. 2000; 18:963-71. | Article | PubMed

124. Anderson JE, Gooley TA, Schoch G, Anasetti C, Bensinger WI, Clift RA, Hansen JA, Sanders JE, Storb R and Appelbaum FR. Stem cell transplantation for secondary acute myeloid leukemia: evaluation of transplantation as initial therapy or following induction chemotherapy. Blood. 1997; 89:2578-85. | Article | PubMed

125. Feldman EJ. Does therapy-related AML have a poor prognosis, independent of the cytogenetic/molecular determinants? Best Pract Res Clin Haematol. 2011; 24:523-6. I Article I PubMed

126. Chang C, Storer BE, Scott BL, Bryant EM, Shulman HM, Flowers ME, Sandmaier BM, Witherspoon RP, Nash RA, Sanders JE, Bedalov A, Hansen JA, Clurman BE, Storb R, Appelbaum FR and Deeg HJ. Hematopoietic cell transplantation in patients with myelodysplastic syndrome or acute myeloid leukemia arising from myelodysplastic syndrome: similar outcomes in patients with de novo disease and disease following prior therapy or antecedent hematologic disorders. Blood. 2007; 110:1379-87. | Article | PubMed Abstract | PubMed Full Text

127. Ostgard LS, Kjeldsen E, Holm MS, Brown Pde N, Pedersen BB, Bendix $\mathrm{K}$, Johansen $\mathrm{P}$, Kristensen JS and Norgaard JM. Reasons for treating secondary AML as de novo AML. Eur J Haematol. 2010; 85:217-26. | Article I PubMed

128. Woodard P, Barfield R, Hale G, Horwitz E, Leung W, Ribeiro R, Rubnitz J, Srivistava DK, Tong $\mathrm{X}$, Yusuf U, Raimondi S, Pui CH, Handgretinger R and Cunningham JM. Outcome of hematopoietic stem cell transplantation for pediatric patients with therapy-related acute myeloid leukemia or myelodysplastic syndrome. Pediatr Blood Cancer. 2006; 47:931-5. | Article | PubMed

129. Aguilera DG, Vaklavas C, Tsimberidou AM, Wen S, Medeiros LJ and Corey SJ. Pediatric therapy-related myelodysplastic syndrome/acute myeloid leukemia: the MD Anderson Cancer Center experience. J Pediatr Hematol Oncol. 2009; 31:803-11. | Article | PubMed

130. Seymour JF, Juneja SK, Campbell LJ, Ellims PH, Estey EH and Prince HM. Secondary acute myeloid leukemia with inv(16): report of two cases following paclitaxel-containing chemotherapy and review of the role of intensified ara-C therapy. Leukemia. 1999; 13:1735-40. | Article | PubMed

\section{Citation:}

van den Berg $\mathrm{H}$. Treatment related myeloid malignancies in childhood. Hematol Leuk. 2014; 2:3. http://dx.doi.org/10.7243/2052-434X-2-3 